\title{
CELL VIABILITY ASSAY OF FICUS BENGHALENSIS LATEX SOLVENT EXTRACTS ON DIFFERENT CELL LINES
}

TULASI CDSLN, LAKSHMI NARASU M, SAIDA L*

Centre for Biotechnology, Institute of Science and Technology, Jawaharlal Nehru Technological Institute, Hyderabad - 600 084, Telangana, India. Email: yrvlm.chidepudi@gmail.com

Received: 09 April 2018, Revised and Accepted: 21 June 2018

\section{ABSTRACT}

Objective: Presented here in the study, the screening for antiproliferative activity of Ficus benghalensis dried latex solvent extracts on human breast MDA MB 231, colorectal HCT116, and neuroblastoma IMR 32 cell lines.

Methods: The anticancer activity of ethanol, methanol, ethyl acetate, and acetone extracts against the above-mentioned cancer cell lines as well in lymphocytes, by 3-(4,5-Dimethylthiazol-2-Yl)-2,5-Diphenyltetrazolium Bromide (MTT) assay and propidium iodide staining was used to observe the morphological changes occurred in the cell due to the affect of latex extract.

Results: Among all the extracts, ethanol extract was found to be effective against IMR 32 and HCT 116 whereas ethyl acetate extract in case of MDA MB 231 cell line with $50 \%$ inhibitory concentration $50 \%$ (IC ${ }_{50}$ ) $123.27 \pm 2.5 \mu \mathrm{g} / \mathrm{ml}, 99.82 \pm 9.06 \mu \mathrm{g} / \mathrm{ml}$, and $75.66 \pm 6.3$, respectively.

Conclusion: The extracts were found to be less toxic on peripheral blood lymphocytes. The $\mathrm{IC}_{50}$ value of the cytotoxic activity measured using MTT dye indicated that the extracts were efficient in inhibition of the cell proliferation of these cell lines.

Keywords: Ficus benghalensis, Latex, Cell viability assay, Lymphocytes, Propidium iodide, Fluorescent microscope.

(C) 2018 The Authors. Published by Innovare Academic Sciences Pvt Ltd. This is an open access article under the CC BY license (http://creativecommons. org/licenses/by/4. 0/) DOI: http://dx.doi.org/10.22159/ajpcr.2018.v11i10.26552

\section{INTRODUCTION}

Cancer is the abnormal growth of the tissue because of lack of regulation in the cell division process. More or less 200 different types of cells in the body were affected with this ailment. Over $50 \%$ of drugs isolated from herbal plants with therapeutic activity were under clinical trials for anticancer activity [1]. Many biological, epidemiological and clinical studies [2-8] confer a strong correlation between dietary habits and lower chance of cancer development. Numerous studies indicated that in many types of cancer cells, dietary agents would induce apoptosis and cell cycle arrest without affecting the normal cells $[9,10]$

Ficus benghalensis (FB) belongs to Moraceae, Mulberry family is generally known as Banyan tree, and in Ayurveda, it is called as Vata or Vata tree. More than 800 species and 2000 varieties of Ficus species, most of which are native to the Old World tropics. FB, a remarkable sacred tree in India, branches, and shoots grow in the direction of gravity, which takes root and becomes new trunk. The leaves of this plant contain crude protein $9.63 \%$, crude fibers $26.84 \%$, $\mathrm{CaO} 2.53 \%$, and phosphorus - $0.4 \%[11,12]$. It yields latex containing resin, albumin, sugar, and malic acid. It is used in Ayurveda for the treatment of dysentery and piles [13,14] teeth disorders [15], diarrhea, rheumatism, to boost immune system [16], skin disorders like sores [17], and as a hypoglycemic [18-21]. The bark of the FB contains leucopelargonidin-3-0- $\alpha$-L rhamnoside glucoside, leucocynidin 3-0- $\alpha$-D galactosyl cellobioside, beta-glucoside, 6-heptatriacontene10-one, 20- tetratriacontane-2-one, pentatriacontane-5-one, meso-inositol [22,11], beta-sitosterol- alpha- D-glucose, 20-tetra tri aconthene -2-one, pentatriacontane-5-one [11,22-26], and 6-heptatriacontene- 10-one. Leaves contain friedelin, rutin, lupeol, $\beta$ - amyrin, and taraxasterol, along with bergapten, psoralen, quercetin3-galactoside, and $\beta$ - sisterol [27].

As a part of the continuous screening of natural compounds from medicinal plants with anticancer properties, the present study is the first report, investigating the cytotoxicity of FB latex extracts on human neuroblastoma cells (IMR 32), human breast adenocarcinoma (MDA MB 231), and human colorectal carcinoma (HCT 116).

\section{METHODS}

\section{General experimental procedures}

Extraction was done in shaker incubator JS Research, JSSi-300C, Korean, cell lines were procured from NCCS, Pune, and the Thermo Multiskan Spectrum Elisa plate reader was used to measure the OD at $540 \mathrm{~nm}$ for 3-(4,5-Dimethylthiazol-2-Yl)-2,5-Diphenyltetrazolium Bromide (MTT) cell viability assay. The morphological changes were visualized under Olympus IX71 phase contrast microscope and fluorescent microscope, photographed using an Olympus Camera.

\section{Collection of plant material}

FB latex, the milky white substance, which turns yellow on standing, was collected into a clean container, from the tree trunk portion by peeling off the bark, during the early hours of the day. Dried latex was then ground to powder and stored in dry airtight containers for the further experimental analysis. Authentication of the plant material was done at the Department of Botany, Andhra University, Visakhapatnam, Andhra Pradesh, as the plant material was collected from university during the fruiting season and deposited in the botany department herbarium with voucher specimen number 22272 .

\section{Extraction}

The latex was dried at $50^{\circ} \mathrm{C}$, powdered and extracted by methods corresponding to the extraction protocols used for natural compounds. The solvents used for extraction were ethyl acetate, acetone, ethanol, and methanol according to the increasing polarity. The ground plant material was percolated with a respective solvent in 10:1 (w/v) for $72 \mathrm{~h}$ placed in shaking incubator at $240 \mathrm{rpm}$ (JS Research, JSSi-300C, Korean), then concentrated to dryness under reduced pressure. The obtained extract was dissolved in DMSO to form a concentration of 
$50 \mathrm{mg} / \mathrm{ml}$, which was filter sterilized before checking its cytotoxic potency.

\section{In vitro assay for cytotoxic activity}

\section{Cell culture}

Cancer cell lines selected for the present study were human neuroblastoma cells (IMR 32), human breast adenocarcinoma (MDA MB 231) and human colorectal carcinoma (HCT 116) were procured from NCCS, Pune. The cells were maintained in RPMI 1640 medium supplemented with $10 \%$ fetal bovine serum, $1 \% 2 \mathrm{mM}$ L-glutamine, $100 \mathrm{IU} / \mathrm{ml}$ penicillin, and $100 \mu \mathrm{g} / \mathrm{ml}$ streptomycin maintained at $37^{\circ} \mathrm{C}$ in a humidified incubator with $5 \% \mathrm{CO}_{2}$. According to their growth rates, the optimum planting density of each cell line was determined to be $5-6 \times 10^{3}$ cells/well in 96 well microtiter plate to maintain exponential growth throughout the experiment.

\section{Cytotoxicity assay}

For the assay, cells were washed with phosphate buffer saline (PBS), treated with $0.025 \%$ trypsin-EDTA (Sigma) $(2 \mathrm{ml}$ ), and flushed with a medium for the uniform cell detachment from the T-flask. The cell suspension with all the viable cells was counted by Trypan blue exclusion using a hemocytometer and then diluted with medium to give the previously determined cell-density $\left(5-6 \times 10^{3}\right.$ cells/well). The cells were then seeded by adding $100 \mu \mathrm{l} /$ well of diluted cell suspension to the 96 well microtiter plate and incubated at $37^{\circ} \mathrm{C}$ for $24 \mathrm{~h}$ ensuring proper and uniform cell attachment to the bottom of the plate. After the incubation period, the cells were treated with extracts which were already dissolved in DMSO stock. The latex extracts were further diluted with medium to make five different concentrations. $100 \mu \mathrm{l}$ of each concentration was loaded in the well in triplicates. Positive control, doxorubicin (DOX) was used at concentrations $0.25 \mu \mathrm{g} / \mathrm{ml}, 0.5 \mu \mathrm{g} / \mathrm{ml}, 0.75 \mu \mathrm{g} / \mathrm{ml}, 1 \mu \mathrm{g} / \mathrm{ml}$, and $1.5 \mu \mathrm{g} / \mathrm{ml}$. The final dilution used for treating cells was made up to $0.4 \%$ of the initial solvent which was used as negative control. The plates were incubated for $24 \mathrm{~h}$. Cell viability was assessed with MTT dye reduction assay with minor modifications $[28,29]$.

The cytotoxic activity of latex extract was calculated as a percentage of cell growth inhibition using the following formula:

$\%$ Growth inhibition $(\%)=\left[\left(\mathrm{A}_{\text {Control }}-\mathrm{A}_{\text {Sample })} / \mathrm{A}_{\text {Control }}\right] \times 100\right.$

Where $A_{\text {control }}$ indicates the absorbance of control containing $0.5 \%$ ethanol-ethyl acetate mixture. $A_{\text {Sample }}$ is the absorbance of treated cells at different concentration. Inhibitory concentration $50 \%\left(\mathrm{IC}_{50}\right)$ values (the concentration of sample required for inhibition of $50 \%$ of cell growth) were obtained from the regression line.

Visualization of cells' morphological changes under the light microscope

The effect of FB latex extracts on the morphology of cells after treating and incubation for $24 \mathrm{~h}$ was visualized under Olympus IX71 phase contrast light microscope. The consumed medium was removed, PBS was added, and the cells were observed and photographed with Olympus Camera attached to the microscope.

Isolation of human peripheral blood mononuclear cells (lymphocytes)

Lymphocytes were isolated from blood of healthy adult volunteer by centrifugation of heparinized venous blood diluted with equal volume of PBS (pH 7.4) over Histopaque 1077 solution (Sigma) at $400 \times \mathrm{g}$ for $30 \mathrm{~min}$ [30]. The interface suspended with lymphocytes was carefully extracted and centrifuged with PBS as well with RPMI 1640 repeatedly ensuring the platelet removal. Trypan blue exclusion was carried out to assess the viability of isolated lymphocytes, and it was found to be $90 \%$. The final cell density was adjusted to about $2 \times 10^{5}$ cells $/ \mathrm{ml}$. The cells were seeded and then immediately treated with the highest concentration of plant extract used in the cytotoxic activity, which is $200 \mu \mathrm{g} / \mathrm{ml}$, and the morphological changes were observed as well cell viability was calculated using MTT assay.

\section{Propidium iodide staining}

This staining technique was used to observe the apoptotic morphological changes happening in the cell due to the action of plant extract. All the cell lines were treated with $\mathrm{IC}_{50}$ concentrations of plant extracts; untreated cells serve as a control in 12 well microtiter plate. After incubation for $24 \mathrm{~h}$, cells were washed with cold PBS, fixed with absolute alcohol and refrigerated for $30 \mathrm{~min}$ at $4^{\circ} \mathrm{C}$, rehydrated with PBS. Propidium iodide solution $(25 \mu \mathrm{M}), 100 \mu \mathrm{l}$ to each well was added and incubated at $37^{\circ} \mathrm{C}$ for $5 \mathrm{~min}$. Photographs were taken using a fluorescent microscope at $200 \times$ magnification.

\section{Statistical analysis}

Values were expressed as the mean \pm standard deviation where $n=3$ for MTT assay. The values were exported to excel sheet, and the IC $\mathrm{I}_{50}$ values were calculated using the regression line plot with $\mathrm{R}^{2}$ value, which determines the variability of response data around its mean value.

\section{RESULTS AND DISCUSSION}

\section{Yield of the plant}

The percentage yield was calculated after extraction was done in all four solvents. The highest percentage yield was obtained in non-polar solvents, ethyl acetate $(7.8 \%)$ and acetone $(6.12 \%)$ whereas lowest was found to be in polar solvents, ethanol (4.12\%) and methanol (3.87\%) (Table 1).

\section{Cytotoxic activity on cell lines}

The antiproliferative effect of FB solvent extracts on MDA MB 231, IMR 32, and HCT 116 was observed with MTT assay. The growth inhibition of the cancer cells was observed in a dose-dependent manner where $90 \%$ inhibition was observed at the highest concentration, $200 \mu \mathrm{g} / \mathrm{ml}$. The IC ${ }_{50}$ values, which id the $50 \%$ inhibition of cell proliferation, were calculated from the basic graphing in Microsoft Excel (Table 2). Ethanolic extract has shown potent cytotoxic activity against IMR 32 as well in HCT 116 with $\mathrm{IC}_{50}(123.27 \mu \mathrm{g} / \mathrm{ml})$ and $\left.\mathrm{IC}_{50} 99.82 \mu \mathrm{g} / \mathrm{ml}\right)$ whereas ethyl acetate extract has shown least $\mathrm{IC}_{50} 75.66 \mu \mathrm{g} / \mathrm{ml}$ ) against MDA MB 231. The positive control, DOX has shown its potency against all the cell lines chosen for the present study (Fig. 1). The Ficus extract has shown best potency against breast cancer cell line.

Ullman et al. gave the first scientific investigation on the activity of fig latex in the 1940s [31-33]. The previous studies have shown the cytotoxic

Table 1: The percentage yield of extract in various solvents

\begin{tabular}{lll}
\hline S. No & Solvent & Yield (w/w\%) \\
\hline 1. & Methanol & 3.87 \\
2. & Acetone & 6.12 \\
3. & Ethyl acetate & 7.8 \\
4. & Ethanol & 4.12 \\
\hline
\end{tabular}

Table 2: $\mathrm{IC}_{50}(\mu \mathrm{g} / \mathrm{ml})$ values of latex extracts on human cancer cell lines

\begin{tabular}{llll}
\hline S. No & Cell lines & FB latex extracts & IC $_{50}(\mu \mathrm{g} / \mathrm{ml})$ \\
\hline 1. & MDA MB 231 & Ethanol & $101.53 \pm 0.3$ \\
& & Methanol & $111.19 \pm 8.02$ \\
& & Acetone & $119.96 \pm 2.55$ \\
& & Ethyl acetate & $75.66 \pm 6.3$ \\
2. & DOX & $0.82 \pm 0.13$ \\
& IMR 32 & Ethanol & $123.27 \pm 2.5$ \\
& & Methanol & $138.02 \pm 6.9$ \\
& & Acetone & $143.3 \pm 2.12$ \\
3. & Ethyl acetate & $167.39 \pm 30.31$ \\
& HCT 116 & DOX & $0.37 \pm 0.05$ \\
& & Ethanol & $99.82 \pm 9.06$ \\
& Methanol & $103.67 \pm 8.4$ \\
& & Acetone & $106.46 \pm 11.27$ \\
& & Ethyl acetate & $130.85 \pm 3.15$ \\
& & DOX & $0.48 \pm 0.3$ \\
\hline
\end{tabular}

FB: Ficus benghalensis, $\mathrm{IC}_{50}$ : Inhibitory concentration $50 \%$, DOX: Doxorubicin 


\begin{tabular}{|c|c|c|c|c|c|c|}
\hline $\begin{array}{l}\text { Cell } \\
\text { line }\end{array}$ & Control & Ethanol & Methanol & Acetone & $\begin{array}{l}\text { Ethyl } \\
\text { Acetate }\end{array}$ & Dox \\
\hline $\mathrm{MDA}$ & & & & & & \\
\hline $\mathrm{MB} 2$ & & & & & & \\
\hline $\mathrm{IMR}$ & & & & & & \\
\hline HCT & & & & & & \\
\hline 116 & & & & & & \\
\hline
\end{tabular}

Fig. 1: Morphological changes at an inhibitory concentration $50 \%$ against all the three selected cell lines. FB A: Ficus benghalensis, acetone extract; FB EA: FB, ethyl acetate extract; FB E: FB, ethanol extract; FB M: FB, methanol extract; DOX: Doxorubicin; and Control: HCT 116 cells

activity of Ficus racemosa hot ethanol bark extract against calu-6 cells using XTT colorimetric assay in a concentration-dependent manner. The cytotoxic effect of plants is predominantly contributed by the presence of secondary metabolites such as alkaloid, steroid, glycoside, terpenoid, tannin, and flavonoid in their extract [34]. The above statement was inconsistent with the present observation because the phytochemical analysis of FB extract has shown the presence of phenols, flavonoids, and alkaloid in significantly higher concentration [35].

\section{Peripheral blood lymphocytes}

The lymphocytes were isolated and were treated with the highest concentration of latex extract used in the cytotoxic activity, $200 \mu \mathrm{g} / \mathrm{ml}$. This concentration was considered for the present study as it has shown almost around $90 \%$ inhibition of cell proliferation in case of cancer cell lines and the aim of this assay is that this concentration should be less toxic to the normal cells like lymphocytes to go along with the theme line that natural products impose less toxicity than the synthetic drugs used to cure the malignancy of the tissue. In this preview, the cell viability was calculated using the MTT assay and was given in Table 3 and Fig. 2. The results indicated that this concentration was considerably less toxic to the lymphocytes and the $\mathrm{IC}_{50}$ concentration will give much lesser impact on the intactness of the lymphocytes.

This study can be considered as the first report on the action of Ficus latex extracts on lymphocytes as per the literature survey. Hence, there is a need for aggressive research to be conducted to know the insights of the mechanism of action of this plant extract on normal cells as well on cancer cell lines.

\section{Propidium iodide staining}

The morphological changes induced in the cancer cells by the plant latex extracts can better be visualized by propidium iodide staining. The morphological changes such a chromatin condensation and fragmentation, distinctive nuclear morphology, loss of cell volume, production of apoptotic bodies and disruption of cell membrane and release of cell organelles, and shrinkage of the cell were observed [36,37]. The cells treated with ethanolic and methanolic latex extracts have shown distinctive shrinkage of cell whereas acetone and ethyl acetate treated cells have shown many nuclei in a single cell (Fig. 3).

\section{CONCLUSION}

The present study has shown the yield of individual extracts from all the four solvent selected for extraction. The cytotoxic activities of all the four solvent extracts were analyzed against the human breast,

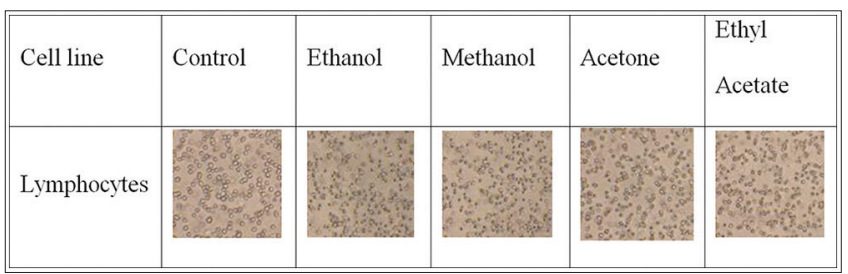

Fig. 2: The morphological changes of lymphocytes when treated with $200 \mu \mathrm{g} / \mathrm{ml}$ Ficus benghalensis latex extracts. FB A: FB acetone extract; FB EA: FB, ethyl acetate extract; FB E: FB, ethanol extract; FB M: FB, methanol extract; and Control: Lymphocytes

Table 3: Cell viability \% of lymphocytes against FB latex extract, $200 \mu \mathrm{g} / \mathrm{ml}$

\begin{tabular}{lll}
\hline S. No & Solvent extract, $\mathbf{2 0 0} \boldsymbol{\mu g} / \mathbf{m l}$ & \% Cell Viability \\
\hline 1 & Ethanol & 60 \\
2 & Methanol & 62 \\
3 & Acetone & 64 \\
4 & Ethyl acetate & 74 \\
\hline FB: Ficus
\end{tabular}

neuroblastoma, and colorectal cell lines. The results have shown that the ethyl acetate extract in the case of breast cancer and ethanol extract in colorectal and neuroblastoma cell lines have exhibited the potent inhibitory activity of cell proliferation. The isolated lymphocytes, when incubated with highest concentration of plant extract has shown minimal toxic effects and calculated the cell viability percentage. The propidium iodide staining indicated that the morphological changes happening in the cancer cells induced by the latex extracts when treated at the established $\mathrm{IC}_{50}$ concentrations. In conclusion, $\mathrm{FB}$ latex extracts were potent enough against cancer cell and inhibited the cell proliferation but least toxic to normal cells, lymphocytes indicating the efficacy of the plant medicinal properties. The further work recommended with this plant could be the analysis of the mechanism of action of the phytochemical targeting the cell signal pathways of apoptosis and necrosis.

\section{ACKNOWLEDGMENTS}

The authors are grateful to Centre for Biotechnology, Institute of Science and Technology, Jawaharlal Nehru Technological University, Hyderabad, for providing bench space to carry out the experimental work. 


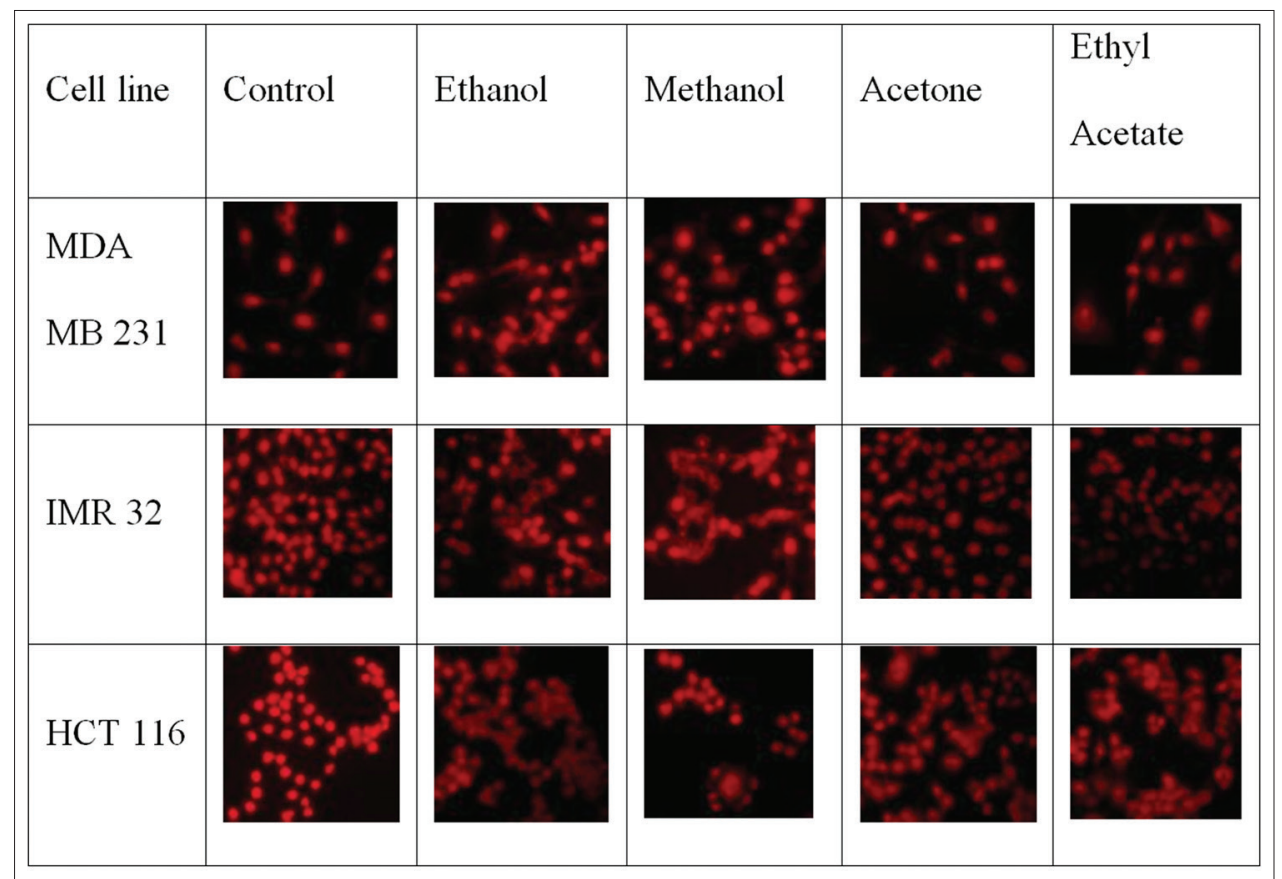

Fig. 3: Morphological changes induced in all the three selected cell lines due to the action of active components present in the latex extract observed under a fluorescent microscope

\section{AUTHOR'S CONTRIBUTION}

CDSLNT conducted the complete experimental work, compiled the data, pictures and prepared the manuscript. MLN and LS designed as well guided the work.

\section{CONFLICTS OF INTEREST}

The authors declare that they have no conflicts of interest.

\section{REFERENCES}

1. Cragg GM, Newman DJ. Antineoplastic agents from natural sources: Achievements and future directions. Expert Opin Investig Drugs 2000;9:2783-97.

2. American Cancer Society. Cancer Facts and Figures. Georgia: American Cancer Society Inc.; 2010.

3. Amr A, Mousa M. Merits of anti-cancer plants from the Arabian Gulf region. Cancer Ther 2007;5:55-66.

4. Anand P, Sundaram C, Jhurani S, Kunnumakkara AB, Aggarwal BB. Curcumin and cancer: An "old-age" disease with an "age-old" solution. Cancer Lett 2008;267:133-64.

5. Campbell CT, Prince M, Landry GM, Kha V, Kleiner HE. Pro-apoptotic effects of 1'-acetoxychavicol acetate in human breast carcinoma cells. Toxicol Lett 2007;173:151-60.

6. Cao P, Cai X, Lu W, Zhou F, Huo J. Growth inhibition and induction of apoptosis in SHG-44 glioma cells by Chinese medicine formula "Pingliu keli”. Evid Based Complement Alternat Med 2011;2011: pii: 958243.

7. Conforti F, Ioele G, Statti GA, Marrelli M, Ragno G, Menichini F, et al. Antiproliferative activity against human tumor cell lines and toxicity test on mediterranean dietary plants. Food Chem Toxicol 2008;46:3325-32.

8. Filomena C, Sosa S, Marrelli M, Menichini F, Statti GA, Uzunov D, et al. The protective ability of Mediterranean dietary plants against the oxidative damage: The role of radical oxygen species in inflammation and the polyphenol, flavonoid and sterol contents. Food Chem 2009:112:587-94.

9. Berquin IM, Edwards IJ, Chen YQ. Multi-targeted therapy of cancer by omega-3 fatty acids. Cancer Lett 2008;269:363-77.

10. Czene S, Testa E, Nygren J, Belyaev I, Harms-Ringdahl M. DNA fragmentation and morphological changes in apoptotic human lymphocytes. Biochem Biophys Res Commun 2002;294:872-8.

11. Subramanian PM, Misra GS. Chemical constituents of Ficus bengalensis (part II). Pol J Pharmacol Pharm 1978;30:559-62.

12. The wealth of India. In: A Dictionary of Indian Raw Materials and
Industrial Products. Vol. 4. New Delhi: Council of Scientific and Industrial Research; 2005. p. 24-6.

13. Mukherjee PK, Saha K, Murugesan T, Mandal SC, Pal M, Saha BP, et al. Screening of anti-diarrhoeal profile of some plant extracts of a specific region of West Bengal, India. J Ethnopharmacol 1998;60:85-9.

14. Husain A, Virmani OP, Popli SP, Misra LN, Gupta MM, Srivastava GN, et al. Dictionary of Indian Medicinal Plants. Lucknow, India: CIMAP; 1992. p. 546.

15. Aiyer KN, Namboodiri AN, Kolammal M. Pharmacognosy of Ayurvedic Drugs. Pharmacognosy Unit. Trivandrum: Ayurveda College; 1957.

16. Gabhe SY, Tatke PA, Khan TA. Evaluation of the immunomodulatory activity of the methanol extract of Ficus benghalensis roots in rats. Indian J Pharmacol 2005;38:271-5.

17. Warrier PK, Nambiar VP, Ramankutty C. Indian Medicinal Plants. Compendium of 500 Species. Madras: Orient Longman Ltd.; 19931995. p. 1-5.

18. Shrotri DS, Aiman R. The relationship of the post-absorptive state to the hypoglycemic action studies on Ficus bengalensis and Ficus glomerata. Indian J Med Res 1960;48:162-8.

19. Deshmukh VK, Shrotri DS, Aiman R. Isolation of a hypoglycaemic principle from the bark of Ficus bengalensis Linn. Indian J Physiol Pharmacol 1960;4:182-5.

20. Augusti KT. Hypoglycaemic action of bengalenoside, a glucoside isolated from Ficus bengalensis Linn, in normal and alloxan diabetic rabbits. Indian J Physiol Pharmacol 1975;19:218-20.

21. Augusti KT, Daniel RS, Cherian S, Sheela CG, Nair CR. Effect of leucopelargonin derivative from Ficus bengalensis Linn. On diabetic dogs. Indian J Med Res 1994:99:82-6.

22. The Wealth of India. In: A Dictionary of Indian Raw Materials and Industrial Products. Vol. 4. New Delhi: Council of Scientific and Industrial Research; 1999. p. 24-6.

23. Subramanian PM, Misra GS. Chemical constituents of Ficusbengalensis. Indian J Chem 1977;15:762.

24. Cherian S, Kumar RV, Augusti KT, Kidwai JR. Antidiabetic effect of a glycoside of pelargonidin isolated from the bark of Ficus bengalensis Linn. Indian J Biochem Biophys 1992;29:380-2.

25. Kumar RV, Augusti KT. Antidiabetic effect of a leucocyanidin derivative isolated from the bark of Ficus bengalensis linn. Indian J Biochem Biophys 1989;26:400-4.

26. Daniel RS, Devi KS, Augusti KT. Mechanism of action of antiatherogenic and related effects of Ficus bengalensis Linn. Flavonoids in experimental animals. Indian J Exp Biol 2003;41:296-303.

27. Chatterjee A. The treaties of Indian medicinal plants. 1997;1:39. 28. Mosmann T. Rapid colorimetric assay for cellular growth and survival: 
Application to proliferation and cytotoxicity assays. J Immunol Methods 1983;65:55-63.

29. Konstantinov SM, Eibl H, Berger MR. BCR-ABL influences the antileukaemic efficacy of alkylphosphocholines. $\mathrm{Br} \mathrm{J}$ Haematol 1999; 107:365-80.

30. Böyum A. Isolation of mononuclear cells and granulocytes from human blood. Isolation of monuclear cells by one centrifugation, and of granulocytes by combining centrifugation and sedimentation at $1 \mathrm{~g}$. Scand J Clin Lab Invest Suppl 1968;97:77-89.

31. Ullman SB, Halberstaedter L, Leibowitz J. Some pharmacological and biological effects of the latex of Ficus carica. Exp Med Surg 1945;3:11-23.

32. Ullman SB. The inhibitory and necrosis-inducing effects of the latex of Ficus carica L. On transplanted and spontaneous tumours. Exp Med Surg 1952;10:26-49.

33. Ullman SB, Clark GM, Roan KM. The effects of the fraction R3 of the latex of Ficus carica L. On the tissues of mice bearing spontaneous mammary tumors. Exp Med Surg 1952;10:287-305.

34. Ozçelik B, Kartal M, Orhan I. Cytotoxicity, antiviral and antimicrobial activities of alkaloids, flavonoids, and phenolic acids. Pharm Biol 2011;49:396-402.

35. Tulasi C, Rani AS, Manjula B. Screening of phyto-chemicals, TLC profiling, total flavonoid and phenolics content, anti-oxidant activity and anti-microbial activity of Ficus benghalensis linn and Ficus religiosa linn latex. Int J Pharm Pharm Sci 2015;7:480-5.

36. Mathi P, Nikhil K, Das S, Roy P, Bokka VR, Botlagunta M. Evaluation of in vitro anticancer activity and Gc-Ms analysis from leaf Sophora interrupta bedd. Int J Pharm Pharm Sci 2015;7:303-8.

37. O'Brein MA, Kirby R. Apoptosis: A review of pro-apoptotic and antiapoptotic pathways and dysregualtion in disease. J Vet Emerg Crit Care 2008; 18:572-85. 